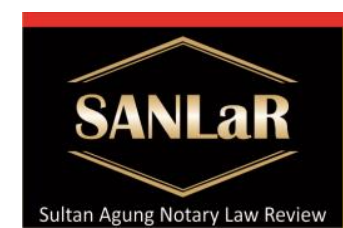

\title{
Position of Foundation Assets from State Assistance
}

\author{
Mohammad Fahdi ${ }^{*}$, Gunarto**), Amin Purnawan ${ }^{* * *}$ )
}

*) Student of Master of Notary Law, Faculty of Law, Universitas Islam Sultan Agung (UNISSULA) Semarang, E-Mail: fahdimuzarie@gmail.com

${ }^{*}$ Lecturer Student of Master of Notary Law, Faculty of Law, Universitas Islam Sultan Agung (UNISSULA) Semarang

*) Lecturer Student of Master of Notary Law, Faculty of Law, Universitas Islam Sultan Agung (UNISSULA) Semarang

\begin{abstract}
The existence of a foundation in the community to achieve various activities, aims and objectives in the social, religious and humanitarian fields has developed rapidly and has more diverse features. However, there are various interpretations of the substance of the Law on Foundations in society, which can lead to uncertainty and legal order. In this connection, a foundation is a legal entity consisting of separated assets of the founder. In addition, the source of the foundation's wealth can be obtained from other sources. A foundation is a legal entity consisting of separated assets of the founder. In addition, the source of the foundation's wealth can be obtained from other sources. Based on the Foundation Law, it is stated that the sources of the Foundation's assets can also be obtained from: donations or assistance that are not binding, waqf, grants, testament grants, and other acquisitions that do not conflict with the articles of association or the prevailing laws and regulations. Donations or non-binding assistances are defined as voluntary donations or assistance received by a foundation, whether from the State, the community or from other parties. This research was conducted to analyze problems arising from the position of the foundation's assets originating from state assistance and to find solutions to the problems that arise. The approach method used in this research is normative juridical which is descriptive-analytical in nature. Primary data is obtained using field research methods, while secondary data is obtained through library research. The collected data were analyzed qualitatively. The results of this study indicate that the management of the foundation is still influenced by the bureaucratic structure when viewed from the composition of the personnel of coaches, administrators and supervisors consisting of former local government officials and the Ministry of Religion of Cirebon Regency.
\end{abstract}

Keywords: Foundation, Assets, State Assistance.

\section{Introduction}

According to the capitalist view, property is the property of individuals, organizations or associations that have a wide and strong network. Meanwhile, according to the socialist view, assets belong to the State as a source of foreign exchange and are in the hands of the ruling party ${ }^{1}$. In Indonesia, there is an organization or association called a foundation, which is a collection of a No. of people who are organized and seen from

\footnotetext{
${ }^{1}$ Qordhowi, Dr. Yusuf. (1995). Waktu Kekuasaan Kekayaan Sebagai Amanah Allah, Fahmi Huwaidy; penerjemah. Jakarta: Gema Insani Press. p. 165
} 
the point of view of their activities, are more visible as social institutions. Where from the beginning, a foundation was established not for commercial institutions or for profit, but its purpose was nothing more than helping or improving the welfare of others.

The existence of a foundation (outside the legal status of the foundation), was initially determined by the will of the founder or the agreement of the founders (founders of the foundation) because they have the same vision that is bound in contract law and then develops in practice. The desire to establish a foundation or an agreement to establish a foundation is then manifested in the form of a notarial deed (notarial deed of establishment of a foundation), and usually this deed determines the objectives of the foundation's establishment, for example social, religious or humanitarian purposes.

In the period prior to the enactment of the Foundation Law, there was a tendency for people to choose the form of a foundation, among other reasons: $\left.{ }^{2} 1\right)$. The establishment process is simple; 2). Without authorization from the Government; and 3). There is a (wrong) perception from the community that a foundation is not a tax subject.

Since its inception, in the concept of Western law, the foundation is an agency intended to be engaged in philanthropic activities, namely non-profit activities in the social and humanitarian fields. A foundation in accordance with its initial principle as a non-commercial (non-profit) legal entity is therefore not allowed to carry out activities in any form of legal action aimed at obtaining profit. ${ }^{3}$ The foundation as a body in Indonesia itself was introduced by the Dutch colonial government, where at that time the foundation was known as "stichting", and to such an agency was given the status of a legal entity which was a phenomenon in the community's legal association since the beginning of the 19 th century. ${ }^{4}$

Utrecht in his book Introduction to Indonesian Law, argues that what is meant by a foundation is any wealth (vermogen) which is not a person's property or body property and which is given a specific purpose. ${ }^{5}$. This implies an understanding that the unclear organizational structure and problems in managing the finances of the foundation is one of the reasons to say that the management of the foundation has not been professionally or traditionally. Meanwhile Soemitro, as quoted by Gatot, stated that the Netherlands already had a new Civil Code and was effective starting in 1977, it appears that the foundation is specifically regulated together with Rechtspersoonen in Book 2 Title 5 Article 285 to Article 305. These articles are carried out systematically regarding the provisions concerning the conditions of its establishment, its position, the authority of its management, amendments to its articles of association, its dissolution, and so on.

\footnotetext{
${ }^{2}$ Setiawan. (1992). Aneka Masalah Hukum dan Hukum Acara Perdata. Bandung: Alumni. p. 201

${ }^{3}$ In the non-profit principle, any existing capital is not processed for profit, but to carry out an activity that is beneficial to society, see Supramono, Gatot. (2008). Hukum Yayasan di Indonesia. Jakarta: Rineka Cipta. p. 110.

${ }^{4}$ Ali, Chaidir. (1999). Badan Hukum. Bandung: Alumni. p. 29

${ }^{5}$ E. Utrecht. (1959). Pengantar Dalam Hukum Indonesia. Print.5, Jakarta: Balai Buku ICHTIAR.p. 278
} 
Whereas in Indonesia after 56 years of independence only had regulations regarding foundations, namely Act No. 16 of 2001 concerning foundations, which were promulgated on August 6, 2001 in the State Gazette of the Republic of Indonesia of 2001 No. 112 and additional RI State Gazette No. 4132, and came into force on 6 August 2002. The enactment of the Foundation Law one year after the date of its promulgation is intended so that the public knows and understands the regulations and can prepare everything related to the foundation ${ }^{6}$.

Thus, the status as a legal entity gives attributes to a foundation like things that are attached to humans as natural legal subjects (natuurlijkepersoon), such as being able to own their own wealth and acting legally on their own behalf through their management. ${ }^{7}$ By paying attention to this theory, it appears that humans as legal subjects are located in individual law, while legal entities are located in the legal field of property. Therefore, legal entities cannot be separated from assets. A legal entity must have its own wealth apart from its equipment or management.

Returning to the Foundation Law, it has been formulated above, that a foundation is a legal entity consisting of separated assets, meaning that a foundation as a legal entity has assets separated from the assets of its management, in other words a foundation has its own assets. These assets are used for the purposes of the foundation. This is in line with Brinz's theory, that the assets of a legal entity are bound by a purpose.

Based on Article 26 paragraph (2) of the Foundation Law, the sources of the proceeds come from; non-binding donations or assistance, endowments, grants, testament grants, and other acquisitions that do not conflict with the articles of association or the prevailing laws and regulations.

In this case, non-binding donations are intended voluntary donations or assistance received by a foundation, whether from the State, the community, or from other parties as long as the assistance does not conflict with the prevailing laws and regulations. Indeed, if there is assistance coming from anywhere, the party providing assistance generally always hopes that there will be "something" that can be done by the recipient of the assistance. The prevailing law in society often states that achievement is always followed by counter-achievement. There are usually aid providers who hope openly, while recipients of assistance sometimes even though they are not asked to make a counter-achievement, on the pretext that they are indebted and then do something for the benefit of the aid provider.

Since the provisions cannot bind the foundation, any party that intends to make a contribution to the foundation must not be binding. If you want to provide assistance, please just give it to the foundation, so that the aid will be handled by the foundation after it is received. On the other hand, foundations as aid recipients must not tie themselves to aid providers. The foundation must be ready to refuse if any assistance is binding on it. ${ }^{8}$

\footnotetext{
${ }^{6}$ Supramono, Gatot. Op. Cit, p. 7-8

${ }^{7}$ According to Munir Fuady, rights as a characteristic inherent in a legal entity as it is known today have actually been known since Roman times, he even said that the concept and theory of legal entities is one of the greatest legal legacies of the Romans to the world today, see Fuady, Munir. (2013). TeoriTeori Besar dalam Hukum. Jakarta: Kencana.p. 164

${ }^{8}$ Op.Cit. p. 69
} 
The foundation law aims to provide the public with the correct understanding and rules regarding foundations, to ensure legal certainty and legal order and to restore the philosophical foundation of foundations as legal institutions in order to achieve certain goals in the social, humanitarian and religious fields. This is as stated in the explanation in the preamble to the Foundation Law. With regard to the enactment of the Foundation Law, it can be said that the Foundation has been recognized as an independent legal subject independent from the position of the legal subject of the founders or its management, where the Foundation can hold rights and obligations, can become a debtor or creditor, so that in other words the Foundation can have any legal relationship with third parties ${ }^{9}$.

In addition, in order to achieve the goals of the state as mandated in the Preamble to the 1945 Constitution, each year the State Revenue and Expenditure Budget / Regional Revenue and Expenditure Budget (APBN / APBD) is prepared to plan activities to be carried out by the government. The budget explains the programs and activities that will be held every year, which are detailed based on the function and type of expenditure.

The expenditure classification according to the type of expenditure consists of personnel expenditure, goods and services expenditure, capital expenditure, interest, subsidies, grants, production sharing and financial assistance expenditures, and unexpected expenditures, as well as social assistance expenditures. ${ }^{10}$ So with APBN funds ${ }^{11}$ available every year, the Government has built many physical facilities and infrastructure to improve the welfare of the Indonesian people.

\section{Research Methods}

Method The research approach used in this writing is to use a descriptive analysis approach, namely a method by describing or describing the facts that occur in society about which then analyzes juridical normative, namely by searching for and finding positive legal aspects in accordance with the problem under study in order to be determined to solve a particular legal problem, in the form of positive law and how it is implemented. Research was carried out on legal principles regarding foundations related to foundation assets based on Act No. 16 of 2001 in conjunction with Act No. 28 of 2004 with in concreto legal research, namely how the status of the foundation's assets originating from state assistance .

\section{Results and Discussion}

Asset is something or property that is owned by a person, business entity, or institution, which has economic value, commercial value and exchange value, where asset can be in the form of immovable goods (land and buildings) or movable property

\footnotetext{
${ }^{9}$ Ferdiyanti, M. Indah Verena., Purnawan, Amin., \& Soegiyanto. (2019). Setting the Effectiveness of Law Position and Code Notary to the Quality of Performance. JURNAL AKTA: Vol. 6, No. 4, 797-804. Retrieved from http://jurnal.unissula.ac.id/index.php/akta/article/view/7887

10 Government Regulation No. 58 of 2005 concerning Regional Financial Management, Article 27 paragraph 7.

${ }^{11}$ Act No. 15 of 2017 Concerning the State Budget
} 
(capital, savings, debt ) which can be considered as assets. In PSAK No. 16 of 2011 Revision states that assets are assets owned by a person or company, both tangible and intangible, valuable or valuable, which will benefit that person or company. According to the Government Accounting Standards (SAP) assets are resources that can provide economic and / or social benefits that are controlled and / or owned by the Government, and can be measured in units of money.

In International Financial Reporting Standards (2008) it is stated that "an asset is a resource controlled by the enterprise as a result of past events and from which future economic benefits are expected to flow to the enterprise"

From the definitions of assets above, several characteristics of assets can be drawn, namely: 1). Assets are economic benefits obtained in the future; 2). Assets are controlled by the company, in the sense that they are controlled by the company; and $3)$. Assets are the result of past transactions or events. However, Article 1 point 1 of the Law on Foundations No. 16 of 2001 states: A foundation is a legal entity consisting of assets that are separated and intended to achieve certain goals in the social, religious and humanitarian fields that do not have members. ${ }^{12}$

According to Adib Bahari, the definition of a foundation above contains four main notes, namely: ${ }^{13}$

1). Foundation is a legal entity. This means that a foundation is legally deemed able to carry out legal actions and have legal consequences, even though it will be obvious that the organ of the foundation will act, either the supervisor, the supervisor or the management.

2). The foundation has segregated wealth. This means that the foundation has assets, whether movable or not, which were initially obtained from separated capital or assets. The foundation legally owns its own independent and independent wealth. ${ }^{14}$ The separation of assets is actually intended to prevent the initial assets of the foundation from still being part of the personal assets or joint assets of the founder. If this is not the case, the property will still remain as the property of the foundation founder.

3). Foundations have certain objectives which are the implementation of values, whether religious, social, or human. From this, it is known that the foundation was designed from the start as a non-profit organization that is not profit oriented as a business entity, such as a limited liability company, CV, Firma and others.

4). The foundation has no members. That is, the foundation does not have some kind of shareholder like a limited liability company or allies in CV or members in other

\footnotetext{
12 Foundation Law

${ }^{13}$ Bahari, Adib. (2001). Prosedur Pendirian Yayasan. Yogyakarta: Pustaka Yustisia. p. 2

${ }^{14}$ Gatot. Op Cit, p. 37
} 
business entities. However, the foundation is of course driven by the organs of the foundation, both supervisors, supervisors and moreover, the main role of organizing the foundation is in the hands of the board and its daily executors.

Article 26 of Act No. 16 of 2001 concerning Foundations states that:

(1) Assets of a foundation come from a No. of assets separated in the form of money or goods.

(2) Apart from the assets referred to in paragraph (1), the assets of the Foundation can be obtained from: ${ }^{15}$ a. donations or assistance that is not binding; b. waqf; c. grant; $d$. will grant; and e. other gains which are not contrary to the Articles of Association of the Foundation and / or the prevailing laws and regulations.

(3) In the event that the assets of a Foundation come from waqf, the provisions of the waqf law shall apply.

(4) The assets of the Foundation as meant in paragraph (1) and paragraph (2) are used to achieve the aims and objectives of the foundation.

Furthermore, in article 27 paragraph (1) of the Foundation Law, that is, in certain cases the State can provide assistance to foundations. In this case, State Assistance is an elaboration of the APBN, which is another name for the State Revenue and Expenditure Budget, namely an economic plan in a government. The form is similar to a list that has been adjusted to a priority scale containing various sources of income in the form of finance and investment in a country. Meanwhile, as it is known, all goods purchased using the APBN or other legal acquisitions become state assets or state property.

More than that, as has been stated in the previous chapter, that the foundation law aims to provide the public with the correct understanding and rules regarding foundations, to ensure legal certainty and legal order and to restore the philosophical foundation of the foundation as a legal institution in order to achieve its goals. Certain in the social, humanitarian and religious fields. This is as stated in the explanation in the preamble to the Foundation Law. With regard to the enactment of the Foundation Law, it can be said that the Foundation has been recognized as an independent legal subject independent from the legal subject position of the founders or its management, where the Foundation can bear rights and obligations, can be a debtor or creditor, so that in other words the Foundation can carry out any legal relationship with third parties. As it is also known, in the period before the issuance of the foundation Act No. 16 of 2001 regarding foundations, there were no clear rules governing foundations, even though in the civil law code, several articles mentioned about foundations, namely the following articles:

${ }^{15}$ Dr. Mulyoto. (2017). Yayasan Rumah Sakit menjadi PT Rumah Sakit. Yogyakarta: Cakrawala. p. 86-87 
365: "In all matters, if the judge has to appoint a guardian, the guardianship may be ordered to an association with legal status domiciled in Indonesia, to a foundation or charity which is also domiciled here, which according to its articles of association, deeds the deed of establishment or its regulation seeks to care for minors for a long time"

899: "With due observance of the provisions of article 2 of this law book, to be able to enjoy something from a will, a person must already exist, when the person who inherits dies"

900: "Any gift giving in a will for the benefit of charities, security agencies, churches or hospitals, will have no consequence, but only to the administrators of these agencies, by the president or by some authority appointed by the president, has been given the power to accept it. "

1680: "Grants to public institutions or religious institutions, have no effect, other than simply by the president or the rulers appointed by him having been given power to the administrators of these institutions, to receive these gifts".

The civil law code states about the existence of a foundation as stated in the articles mentioned above, but these articles do not regulate the foundation in detail, including its definition, establishment, purpose and purpose. This has implications for foundations where foundations are not only established with a non-profit nature, but on the other hand there are foundations which are used by certain parties to pursue profits even though at the beginning of their establishment there were various justifications created.

Based on the results of field research, the Problem of the Cirebon Regency Islamic Center Foundation, formerly the Baitul Mal Foundation, at the address is St. Tuparev No. 111 Cirebon, was founded by the Regional Amil Zakat Agency (Bazda) Level II of Cirebon Regency, not by a founding body which is usually a supervisor. Therefore the position of the foundation is under Bazda, organs and administrators are formed and appointed by the Regent as the General Chair of Bazda. Until now, even though the Foundation Management is confirmed by a Notary Deed and has separated from Bazda and has adjusted it to Act No. 16 of 2001 concerning Foundations as amended by Act No. 28 of 2004 concerning amendments to Act No. 16 of 2001 concerning Foundations and has been approved by the Minister of Law and Human Rights.

The assets of the Cirebon Regency Islamic Center Foundation consist of land and buildings. Land assets include state land (village land) obtained through a swap and land obtained through purchases. Meanwhile, building or building assets include state assistance through grants or social assistance and through community organizations. The problems with the foundation's assets are as follows: The problem with the foundation's assets is an area of land around 40,035 $\mathrm{m}^{2}$, recorded in certificate No. $41 / 1997$, located in Kertawinagun village is village land. However, it was obtained through a process of swapping (Rislah) with the purchased land in Dawuan village. The land in Dawuan village belongs to the community and is purchased by the foundation using funds from the community, then sold and the money is handed over to the Kertawinangun Village Government to find replacement land. Thus the foundation's 
assets covering an area of 40,035 $\mathrm{m} 2$ do not come from state assistance, but from nongovernmental organizations.

As a solution to solving the problem of the foundation's assets in the form of land, both land originating from the swap covering an area of 40,035 $\mathrm{m} 2$ and land obtained from the purchase, namely land an area of 3,915 m2 (certificate No. 68/2013), and an area of $347 \mathrm{~m} 2$ (certificate No. 79/2017) and an area of $213 \mathrm{~m} 2$ (certificate in process), because the land assets by BPN were given the right to use or rights to build (HGB) varying degrees, ranging from 10 years, 20 years to 30 years, the Management immediately stepped into BPN to confirm why this happened. This step is important to know the legal basis for granting land rights to foundations, especially in terms of the foundation's assets that come from community organizations in the form of shadaqah, donations, grants and waqf.

As for the solution to the problem of assets in the form of buildings or buildings either built with funding from grants or assistance from the State or from non-governmental organizations, the Foundation tries to identify buildings that come from state assistance and buildings that come from non-governmental organizations. This is important because it is to determine community participation and at the same time to know the level of independence of the Foundation.

\section{Closing}

Problems with foundations related to assets originating from Government assistance that are directly handed over to the institution have resulted in difficulties for the Foundation to know in detail the income and expenditure of each institution's funds, so it is recommended that institutions that receive assistance from the Government make a double report, which first addressed to the Government as accountability and second addressed to foundations as a report. And for regulatory provisions regarding the position of foundation assets originating from state assistance should provide clear regulations regarding the position of these assets so that there is no overlap with regard to policies, so that they have the opportunity to harm foundations or third parties or to the State.

\section{References}

Journals:

Ferdiyanti, M. Indah Verena., Purnawan, Amin., \& Soegiyanto. (2019). Setting the Effectiveness of Law Position and Code Notary to the Quality of Performance. JURNAL AKTA: Vol. 6, No. 4, 797-804. Retrieved from http://jurnal.unissula.ac.id/index.php/akta/article/view/7887

Books:

[1] Ali, Chaidir. (1999). Badan Hukum. Bandung: Alumni 
[2] Bahari, Adib. (2001). Prosedur Pendirian Yayasan. Yogyakarta: Pustaka Yustisia

[3] Dr. Mulyoto. (2017). Yayasan Rumah Sakit menjadi PT Rumah Sakit. Yogyakarta: Cakrawala

[4] E. Utrecht. (1959). Pengantar Dalam Hukum Indonesia. Print.5, Jakarta: Balai Buku ICHTIAR

[5] Fuady, Munir. (2013). Teori-Teori Besar dalam Hukum. Jakarta: Kencana

[6] Qordhowi, Dr. Yusuf. (1995). Waktu Kekuasaan Kekayaan Sebagai Amanah Allah, Fahmi Huwaidy; penerjemah. Jakarta: Gema Insani Press

[7] Setiawan. (1992). Aneka Masalah Hukum dan Hukum Acara Perdata. Bandung: Alimni

[8] Supramono, Gatot. (2008). Hukum Yayasan di Indonesia. Jakarta: Rineka Cipta

Regulations:

[1] Act No. 16 of 2001 concerning Foundations.

[2] Act No. 28 of 2004 concerning amendments to Act No. 16 of 2001 concerning Foundations.

[3] Act No. 17 of 2003 concerning State Finance.

[4] Act No. 1 of 2004 concerning State Treasury

[5] Act No. 07 of 1983 concerning Income Tax

[6] Government Regulation No. 63 of 2008 concerning the implementation of the Law on Foundations

[7] Government Regulation No. 2 of 2013 concerning Amendments to Government Regulation No. 63 of 2008 concerning the implementation of the Law on Foundations

[8] Government Regulation No. 6 of 2006 concerning State Property Management

[9] Government Regulation No. 58 of 2005 concerning Regional Financial Management

[10]Permenkumham No. 2 of 2016 concerning Procedures for Submitting Applications for Ratification of Legal Entities and Approval of Amendments to Articles of Association and Notification of Amendments to Articles of Association and Amendments to Foundation Data 